\title{
DUKUNGAN SOSIAL KELUARGA DENGAN SELF ESTEEM PADA NARAPIDANA NARKOBA YANG DIREHABILITASI DI LAPAS NARKOTIKA YOGYAKARTA
}

\author{
Elia Febry Herniron Bandi ${ }^{1}$, Christiana Hari Soetjiningsih ${ }^{2}$ \\ E-mail :elyabandi@gmail.com ${ }^{1}$ \\ Fakultas Psikologi Universitas Kristen Satya Wacana Salatiga ${ }^{1,2}$
}

\begin{abstract}
Abstrak
Penelitian ini bertujuan untuk mengetahui hubungan antara dukungan sosial keluarga dengan self esteem pada narapidana narkoba yang direhabilitasi di Lapas Narkotika Yogyakarta. Partisipan penelitian ini berjumlah 32 narapidana narkoba yang sedang direhabilitasi di blok edelweis Lapas Narkotika Yogyakarta. Alat pengumpulan data yang digunakan dalam penelitian ini yaitu skala dukungan sosial keluarga terdiri dari 24 aitem yang diadaptasi dari Social Provisions Scale yang dibuat oleh Cutrona dan Russel (1987) dan skala self esteem terdiri dari 54 aitem yang diadaptasi dari Coopersmith Self-Esteem Inventory (1967). Analisis data dilakukan dengan teknik korelasi Product Moment-Pearson dengan bantuan SPSS versi 22. Hasil analisis data menunjukkan $\mathrm{r}=0,547$ dengan nilai sig. $=0,001(\mathrm{P}<0,05)$ yang berarti terdapat hubungan positif yang signifikan antara dukungan sosial keluarga dengan self esteem pada narapidana narkoba yang direhabilitasi.
\end{abstract}

Kata Kunci : Dukungan Sosial Keluarga; Self Esteem; Narapidana Narkoba; Rehabilitasi

PENDAHULUAN

Penyalahgunaan narkoba semakin meluas dan bertambah di Indonesia. Data Badan Narkotika Nasional Republik Indonesia (2017) menunjukkan jumlah kasus narkoba per tahunnya mengalami peningkatan. Angka prevalensi narkoba di Indonesia pada tahun 2017 dilaporkan $1,7 \%$ dengan jumlah penyalahguna mencapai 3.376 .115 orang. Para penyalahguna narkoba yang telah terbukti melanggar hukum yang berlaku akan dimasukkan kedalam Rumah Tahanan atau Lembaga Pemasyarakatan.

Lembaga Pemasyarakatan Narkotika yang dikhususkan bagi narapidana kasus narkoba, berdiri sendiri dan pola pembinaannya berbeda dengan Lembaga Pemasyarakatan umum. Narapidana narkoba merupakan bagian dari narapidana dengan kondisi yang berbeda dan spesifik, yaitu mempunyai karakter atau perilaku yang cenderung berbeda akibat penggunaan narkoba yang dikonsumsi mereka selama ini, seperti kurangnya tingkat kesadaran akibat rendahnya kemampuan penyerapan, keterpurukan kesehatan dan sifat over reaktif dan over produktif. Dampak psikologi yang ditimbulkan akibat penggunaan narkoba adalah lamban kerja, ceroboh kerja, sering tegang dan gelisah, hilang kepercayaan diri, apatis, pengkhayal, penuh curiga, agitatif, menjadi ganas dan tingkah laku yang brutal, sulit berkonsentrasi, perasaan kesal dan tertekan, cenderung menyakiti diri, perasaan tidak aman, bahkan bunuh diri, gangguan mental, anti-sosial dan asusila, dikucilkan oleh lingkungan, merepotkan 
dan menjadi beban keluarga serta pendidikan menjadi terganggu, masa depan suram. Akibatnya narapidana narkoba perlu penanganan khusus daripada narapidana kasus lain selama berada di Rumah Tahanan ataupun Lembaga Pemasyarakatan (Kristianingsih, 2009).

Lapas Narkotika Yogyakarta merupakan tempat yang digunakan untuk menampung para narapidana kasus narkotika. Jumlah keseluruhan narapidana di Lapas Narkotika Yogyakarta per Oktober 2018 berjumlah 315 orang narapidana pria dan jumlah narapidana yang berada di blok edelweis berjumlah 35 orang. Blok edelweis merupakan blok yang dikhususkan untuk program rehabilitasi bagi narapidana penyalahguna narkoba. Program rehabilitasi narkoba merupakan upaya terpadu yang meliputi program medis dan non-medis atau sosial dengan tujuan membantu penyalahguna narkoba melepaskan diri dari jeratan ketergantungan narkoba, meningkatkan kemampuan penyesuaian diri, membangun kepercayaan diri, dan meningkatkan kemampuan fungsional mereka sesuai dengan potensi yang dimiliki.

Sejak tahun 2015 Lapas Narkotika Yogyakarta bersama BNNP DIY dan Kanwil Kemenkumham DIY telah diberikan wewenang untuk menyelenggarakan rehabilitasi bagi para narapidana narkoba. Pada tahun 2015, sebanyak 32 narapidana yang merupakan pecandu dan penyalahguna berhasil direhabilitasi. Rehabilitasi dilakukan dengan metode terapi berbasis komunitas meliputi konseling individu, kelompok, keluarga, narcotic anonymus dan bimbingan rohani. Rehabilitasi diselenggarakan selama tiga bulan. Dalam dua minggu pertama, peserta rehabilitasi menjalani perbaikan mental dan fisik, dan selama delapan minggu berikutnya mulai menjalani rehabilitasi. Sedangkan, dua minggu berikutnya merupakan persiapan menghadapi program pasca rehabilitasi, yang bisa dilakukan di klinik milik BNNP DIY atau lembaga kesehatan lainnya. Sementara bagi peserta rehabilitasi, sebelumnya harus menjalani proses assessment atau pembuktian jika memang layak dan memenuhi syarat untuk mendapatkan rehabilitasi (Kemenkumham DIY, 2016).

Peneliti telah melakukan wawancara pada studi pendahuluan terhadap 5 informan dari 35 orang narapidana yang berada di Blok Edelweis. Mereka mengatakan bahwa kegiatan rehabilitasi memiliki dampak yang beragam pada kehidupannya. Tiga orang narapidana mengevaluasi dirinya berubah menjadi 
lebih baik ketika mengikuti program rehabilitasi. Mereka mengakui adanya penghargaan dan penerimaan dari orang lain terhadap ide dan hak mereka. Perhatian dan kasih sayang juga ditunjukkan oleh petugas Lapas, sesama narapidana maupun keluarga. Mereka juga sering menghasilkan karya seni berupa lukisan, puisi, properti dari kulit, serta kerajinan tangan lainnya. Ketaatan mereka terhadap aturan Lapas dan kemampuan memberi contoh bagi narapidana lain menimbulkan penerimaan lingkungan yang tinggi, sehingga mereka bertiga dijadikan tahanan pendamping (tamping) dan menjadi koordinator untuk berbagai kegiatan oleh para petugas Lapas Narkotika Yogyakarta. Hal tersebut membuat mereka merasa berarti karena mendapat kepercayaan, perhatian serta dipandang mampu oleh petugas Lapas, karena berbagai kemampuan dan keterampilan yang dimiliki, maka para narapidana tersebut mendapat respon positif dari orang sekitarnya.

Namun dua narapidana mengatakan bahwa tidak ada yang berubah dengan dirinya selama mengikuti program rehabilitasi. Mereka menilai bahwa dirinya tidak berguna selama berada di Lapas karena kurangnya kepercayaan diri untuk melakukan segala sesuatu. Hal lain yang menyebabkan tidak adanya perubahan yaitu mereka masih mengalami sugesti untuk menggunakan narkoba kembali. Ketakutan akan stigma dan diskriminasi dari masyarakat akan penerimaan kembali mantan narapidana narkoba juga menyebabkan mereka merasa tidak berguna. Akibatnya mereka merasa dirinya tidak berharga dan rendah diri. Nampak dari perilaku narapidana yang cenderung menyendiri, sulit berinteraksi dengan orang baru, serta ragu dalam menyelesaikan suatu pekerjaan yang diberikan. Ada yang menilai dirinya menjadi individu yang lebih baik dan ada juga yang menilai dirinya tidak berubah selama mengikuti program rehabilitasi di blok edelweis. Penghayatan diri sendiri menjadi individu yang lebih baik atau merasa tidak berubah berkaitan dengan harga diri atau self esteem.

Menurut Coopersmith (1967) self esteem mengacu pada evaluasi yang dilakukan individu dan biasanya dipertahankan sehubungan dengan dirinya sendiri; itu dinyatakan dalam sikap persetujuan atau ketidaksetujuan, dan melampirkan sejauh mana individu percaya dirinya mampu, penting, berhasil dan berharga. Singkatnya, harga diri adalah penilaian pribadi atas kelayakan yang dinyatakan dalam sikap yang dipegang individu terhadap dirinya sendiri. Coopersmith (1967) menyebutkan 
terdapat empat aspek self esteem yaitu : 1) Power yang berkaitan dengan kemampuan individu dalam mengatur dan mengontrol perilaku agar mendapatkan pengakuan dari orang lain atas perilaku tersebut. 2) Significance berkaitan dengan kepedulian, perhatian, afeksi dan ekspresi cinta yang diterima oleh individu dari orang lain yang menunjukkan adanya penerimaan dan popularitas individu dari lingkungan sosial. 3) Virtue berkaitan dengan ketaatan seorang individu untuk mengikuti standar moral dan etika agama dalam kehidupan bermasyarakat. 4) Competence berkaitan dengan pencapaian tertinggi seorang individu untuk memenuhi kebutuhan dan mencapai prestasi (need of achievement), semua itu tergantung dari variasi usia individu.

Kegiatan rehabilitasi yang telah dilakukan bertujuan untuk memulihkan kondisi fisik dan psikologis narapidana, salah satunya meningkatkan self esteem narapidana di blok rehabilitasi. Menurut Coopersmith (1967) faktor-faktor yang memengaruhi self esteem adalah jenis kelamin, intelegensi, kondisi fisik, lingkungan keluarga dan lingkungan sosial. Penghargaan, penerimaan, dan juga perlakuan positif yang didapat dari lingkungan sekitar, termasuk juga orangorang terdekatnya seperti keluarga merupakan bentuk penguatan self esteem untuk bisa keluar dari penyalahgunaan zat (Mann, dkk., 2004). Namun, hasil penelitian Nelfice (2014) menunjukkan bahwa tidak ada hubungan antara dukungan keluarga dengan harga diri remaja di Lembaga Pemasyarakatan. Atas dasar hasil penelitian yang dilakukan oleh Alavi (2011) mengenai peran harga diri dalam kecenderungan terhadap narkoba, pencurian dan pelacuran dapat disimpulkan bahwa mereka yang terlibat kecanduan, pencurian dan pelacuran memiliki harga diri yang lebih rendah dibandingkan dengan orang biasa. De Leon (2000) menyebutkan bahwa self esteem dari pecandu narkoba secara umum berada pada tingkat yang rendah (low self esteem). Jadi, perlu untuk meningkatkan harga diri seseorang untuk mengurangi kecenderungan mereka untuk kecanduan. Adanya perlakuan positif dari orang-orang terdekat narapidana dapat menimbulkan perasaan keberhargaan diri dan kesadaran akan nilai dirinya sehingga narapidana akan mampu berguna bagi orang-orang terdekat dan lingkungannya. Hal tersebut dapat disebutkan sebagai bentuk dukungan sosial.

Menurut Cutrona (1987) dukungan sosial didefinisikan sebagai suatu proses hubungan yang terbentuk dari individu dengan persepsi bahwa seseorang dicintai dan dihargai, disayangi, untuk 
memberikan bantuan terhadap individu yang mengalami tekanan-tekanan didalam hidupnya. Cutrona (1987) menyebutkan ada enam aspek dari dukungan sosial yaitu : 1) Guidance yaitu nasihat atau informasi yang didapatkan individu dari orang lain. 2) Reliable alliance yaitu adanya jaminan bahwa individu memiliki orang yang bisa diandalkan dalam memberikan dukungan, biasanya didapatkan dari keluarga. 3) Reassurance of worth yaitu adanya pengakuan dari orang lain bahwa individu berharga serta berkompeten. 4) Oppurtunity of nurturance yaitu adanya perasaan bahwa seseorang sesorang mempercayakan sesuatu kepada individu yang berhubungan dengan skema konseptualnya. 5) Attachment yaitu adanya kedekatan emosional dari seseorang yang memberikan rasa aman. 6) Social integration yaitu rasa memiliki suatu kelompok yang memiliki kesamaan minat, aktivitas dan perhatian. Dukungan sosial bisa didapatkan dari lingkungan informal (keluarga, teman, rekan kerja, atasan) dan dari lingkungan bantuan formal (pekerja kesehatan, pekerja jasa kemanusiaan). Penelitian yang dilakukan oleh Alboukordi dkk., (2010) mengenai hubungan antara harga diri dan dukungan sosial dengan depresi pada narapidana pria di Shiraz menunjukkan bahwa harga diri adalah faktor prediktif untuk depresi pada tahanan, sedangkan dukungan sosial tidak menunjukkan hubungan yang signifikan.

Keberadaan narapidana di Lapas tidak menghilangkan hak mereka untuk bertemu dengan keluarga yang berada diluar Lapas. Narapidana yang berada di blok edelweis mengatakan bahwa mereka sangat membutuhkan dukungan dari keluarga. Saat kunjungan, setiap anggota keluarga dapat bertemu untuk mempertahankan ikatan keluarga dan dapat membantu proses rehabilitasi pada narapidana tersebut (Dixey \& Woodal, 2012). Hal tersebut sesuai dengan hasil penelitian yang dilakukan oleh Nurhidayati (2014) yang menunjukkan bahwa terdapat korelasi yang signifikan antara dukungan sosial keluarga dengan self esteem pada penyalahguna narkoba yang direhabilitasi. Namun, temuan dari penelitian Jiang (2006) mengenai dukungan sosial, gender dan penyesuaian tahanan untuk kehidupan penjara menunjukkan bahwa narapidana pria kurang mendapatkan dukungan sosial dibandingkan narapidana wanita. Tiga narapidana yang menilai dirinya berubah menjadi lebih baik, mengatakan bahwa mereka mendapatkan banyak dukungan dari keluarga. Sedangkan dua narapidana yang menilai tidak ada perubahan dalam dirinya, mengatakan bahwa jarang sekali 
mendapatkan dukungan sosial dari keluarganya. Bentuk dukungan yang didapatkan seperti kunjungan, finansial, nasihat, kepedulian, motivasi dan kasih sayang. Dukungan yang didapatkan dari keluarga membuat narapidana yang direhabilitasi merasa berharga, sehingga dapat memperkuat tekad mereka untuk terlepas dari narkoba.

Hasil penelitian sebelumnya mengenai hubungan antara dukungan sosial keluarga dan self esteem memiliki hasil yang beragam. Hasil penelitian Husnina (2016) mengenai social support dari significant others dengan self esteem pada Andikpas di LPKA Kelas II Bandung memperlihatkan bahwa terdapat hubungan positif yang tinggi. Namun, penelitian yang dilakukan oleh Herdiyanto (2014) mengenai hubungan antara dukungan sosial keluarga dan self esteem pada remaja penyalahguna zat yang sedang dalam masa rehabilitasi mendapatkan hasil bahwa tidak terdapat hubungan yang signifikan.

Berdasarkan paparan yang telah diuraikan maka rumusan masalah penelitian ini yaitu apakah ada hubungan antara dukungan sosial keluarga dengan self esteem pada narapidana narkoba yang direhabilitasi di Lapas Narkotika Yogyakarta. Tujuan dari penelitian ini untuk mengetahui hubungan antara dukungan sosial keluarga dengan self esteem pada narapidana narkoba yang direhabilitasi di Lapas Narkotika Yogyakarta.

\section{METODE PENELITIAN}

Penelitian ini menggunakan pendekatan kuantitatif. Jenis penelitian korelasional yaitu penelitian yang dirancang untuk menentukan tingkat hubungan antara variabel-variabel yang berbeda dalam suatu populasi. Alasan peneliti menggunakan penelitian korelasional karena penelitian ini bertujuan untuk mengetahui hubungan antara dua variabel yaitu dukungan sosial keluarga dan self esteem. Penelitian ini dilakukan di blok Edelweis yaitu blok rehabilitasi di Lapas Narkotika Yogyakarta.

Partisipan dalam penelitian ini adalah narapidana narkoba yang sedang menjalani proses rehabilitasi di blok edelweis Lapas Narkotika Yogyakarta yang berjumlah 32 orang berjenis kelamin laki-laki. Teknik pengambilan sampel menggunakan sampel jenuh yaitu teknik penentuan sampel apabila semua anggota populasi digunakan sebagai sampel.

Alat pengumpulan data yang digunakan dalam penelitian ini yaitu skala dukungan sosial keluarga menggunakan Social Provisions Scale yang dibuat oleh Cutrona, C. E. \& Russel, D. W. (1987) 
yang terdiri dari 24 aitem dan terdiri dari 6 aspek. Sedangkan skala self esteem menggunakan Coopersmith Self-Esteem Inventory (1967) yang dibuat oleh Coopersmith S. yang terdiri dari 54 aitem dan terdiri dari 4 aspek.

Penelitian ini adalah untuk mencari hubungan antara variabel dukungan sosial keluarga dan self esteem, sehingga analisis data menggunakan uji korelasi Product Moment-Pearson. Perhitungan dilakukan dengan bantuan program SPSS versi 22 .

\section{HASIL DAN PEMBAHASAN}

\section{Kriteria Skor Dukungan Sosial}

\section{Keluarga}

\begin{tabular}{cccc}
\hline Interval & Kategori & Frekuensi & \% \\
\hline $52<x \leq 64$ & Sangat Tinggi & 11 & $34,38 \%$ \\
\hline $40<x \leq 52$ & Tinggi & 21 & $65,62 \%$ \\
\hline $28<x \leq 40$ & Rendah & - & - \\
\hline $16 \leq x \leq 28$ & Sangat Rendah & - & - \\
\hline
\end{tabular}

Berdasarkan presentase yang diperoleh, dukungan sosial keluarga sebagian besar $(65,62 \%)$ narapidana narkoba yang direhabilitasi di Lapas Narkotika Yogyakarta ini berada pada kriteria yang tinggi.

\section{Kriteria Skor Self Esteem}

\begin{tabular}{cccc}
\hline Interval & Kategori & Frekuensi & $\%$ \\
\hline $113,75<\mathrm{x} \leq 140$ & Sangat Tinggi & 5 & $15,62 \%$ \\
\hline $87,5<\mathrm{x} \leq 113,75$ & Tinggi & 25 & $78,12 \%$ \\
\hline $61,25<\mathrm{x} \leq 87,5$ & Rendah & 1 & $3,13 \%$ \\
\hline $35 \leq \mathrm{x} \leq 61,25$ & Sangat Rendah & 1 & $3,13 \%$
\end{tabular}

Berdasarkan presentase yang diperoleh, maka self esteem sebagian besar $(78,12 \%)$ narapidana narkoba yang direhabilitasi di
Lapas Narkotika Yogyakarta ini berada pada kriteria yang tinggi.

\begin{tabular}{|c|c|c|c|}
\hline \multicolumn{4}{|c|}{ Correlations } \\
\hline & & $\overline{D S K}$ & $\overline{\mathrm{SE}}$ \\
\hline \multirow[t]{2}{*}{$\overline{D S K}$} & $\begin{array}{l}\text { Pearson Correlation } \\
\text { Sig. (1-tailed) }\end{array}$ & 1 & $\begin{array}{r}.547^{* * *} \\
.001\end{array}$ \\
\hline & $\mathrm{N}$ & 32 & 32 \\
\hline \multirow[t]{2}{*}{$\overline{\mathrm{SE}}$} & $\begin{array}{l}\text { Pearson Correlation } \\
\text { Sig. (1-tailed) }\end{array}$ & $\begin{array}{r}.547^{\text {*** }} \\
.001\end{array}$ & 1 \\
\hline & $\mathrm{N}$ & 32 & 32 \\
\hline
\end{tabular}

Berdasarkan hasil perhitungan uji korelasi Product Moment-Pearson dengan bantuan SPSS 22 didapatkan $r=0,547$ dengan sig. $=0,001 \quad(\mathrm{P}<0,05) . \quad$ Hasil tersebut menunjukkan adanya korelasi positif yang signifikan antara dukungan sosial keluarga dengan self esteem. Makin tinggi dukungan sosial keluarga maka makin tinggi self esteem, dan sebaliknya makin rendah dukungan sosial keluarga maka makin rendah self esteem pada narapidana narkoba yang direhabilitasi di Lapas Narkotika Yogyakarta. Sumbangan efektif dukungan sosial keluarga terhadap self esteem yaitu $(0,547)^{2} \times 100 \%=29,92$ $\%$.

\section{Pembahasan}

Partisipan dalam penelitian ini adalah 32 narapidana narkoba pria yang sedang menjalani rehabilitasi di blok edelweis Lapas Narkotika Yogyakarta. Rentang usia partisipan antara 18 sampai dengan 40 tahun. Latar belakang pendidikan beragam dari SD, SMP, SMA 
bahkan Perguruan Tinggi. Sebagian besar partisipan belum menikah dan masih tinggal bersama orangtua. Jenis narkoba yang dipakai partisipan sebelumnya adalah ganja, shabu-shabu, tembakau gorila dan putau.

Berdasarkan hasil perhitungan korelasi Product Moment-Pearson antara variabel dukungan sosial keluarga dengan self esteem menunjukan $\mathrm{r}=0,547$ dengan sig. $=0,001 \quad(\mathrm{P}<0,05)$. Hasil tersebut menunjukkan bahwa terdapat hubungan positif dan signifikan antara dukungan sosial keluarga dengan self esteem pada narapidana narkoba yang direhabilitasi di Lapas Narkotika Yogyakarta. Makin tinggi dukungan sosial keluarga, maka makin tinggi self esteem. Hasil penelitian ini sesuai dengan penelitian sebelumnya yang telah dilakukan oleh Nurhidayati \& Nurdibyanandaru (2014) mengenai dukungan sosial keluarga dengan self esteem pada penyalahguna narkoba yang direhabilitasi, menemukan bahwa dukungan dari keluarga cukup memegang peranan penting dalam meningkatkan self esteem pada penyalahguna narkoba dalam masa rehabilitasi.

Hasil penelitian ini menyatakan bahwa sebagian besar narapidana narkoba yang direhabilitasi mendapatkan dukungan sosial keluarga yang tinggi. Hal ini disebabkan karena sebagian besar narapidana berasal dari Kota Yogyakarta, sehingga keluarganya sering melakukan perkunjungan dan memberikan dukungan secara langsung. Dukungan tersebut meliputi guidance, reliable alliance, reassurance of worth, opportunity for nurturance, attachment dan social integration. Narapidana narkoba yang sedang direhabilitasi mengevaluasi dirinya dihargai, dicintai, disayangi dan mendapat bantuan dari keluarganya. Dukungan sosial dari keluarga terhadap seorang narapidana berdampak positif pada harga diri dan kualitas hidup mereka karena narapidana merasa diperhatikan, tidak merasa kesepian dan mempunyai tempat untuk mengungkapkan setiap permasalahan yang mereka alami selama berada di Lapas. Mereka merasa lebih berharga dan dicintai karena keluarga selalu ada disaat mereka membutuhkan bantuan. Hal tersebut sesuai dengan teori yang dikemukakan oleh Papalia (2008) bahwa pemberian dukungan sosial dari orang-orang yang berarti disekitar kehidupan akan memberikan kontribusi yang signifikan dalam proses penyembuhan ketergantungan narkoba. Adanya keeratan hubungan antara dukungan dengan ketepatan waktu pemberian dukungan, maka dukungan keluarga menjadi optimal pada situasi dan 
kondisi pada narapidana narkoba di Lapas Narkotika Yogyakarta.

Dukungan sosial merupakan salah satu faktor penting dalam pembentukan self esteem. Keluarga terutama orangtua adalah sumber bantuan dan dukungan utama dalam pembentukan self esteem (Myers, 2012). Dukungan keluarga yang diterima oleh narapidana narkoba yang direhabilitasi menumbuhkan rasa keberhargaan dalam diri. Narapidana yang merupakan penyalahguna narkoba apabila mendapatkan dukungan sosial dari keluarga terutama kedua orangtuanya, maka dapat membantu, membimbing atau mengantarkannya untuk menjalani rehabilitasi sebagai bentuk usaha untuk lepas dari kecanduan narkoba. Kepedulian, perhatian dan afeksi yang diterima individu melalui dukungan sosial keluarga adalah salah satu sumber self esteem (Coopersmith, 1967). Hal ini sesuai dengan pendapat Mann, dkk., (2004) yaitu penghargaan, penerimaan, dan juga perlakuan positif yang didapat dari lingkungan sekitar, termasuk juga orang-orang terdekatnya seperti keluarga merupakan bentuk penguatan self esteem untuk bisa keluar dari penyalahgunaan zat. Dukungan yang diterima oleh narapidana narkoba dari keluarga menyebabkan narapidana merasa berharga, yang dapat membantu serta memperkuat tekadnya agar bisa berhenti dan terbebas dari narkoba selamanya.

Dalam penelitian ini sebagian besar narapidana narkoba yang direhabilitasi memiliki self esteem pada kategori tinggi. Hal ini disebabkan karena narapidana mempersepsikan dukungan dari keluarga merupakan salah satu bentuk dukungan terbesar dalam masa tahanan maupun rehabilitasinya. Sehingga narapidana merasa lebih dihargai oleh orang-orang sekitar terutama keluarganya. Narapidana dengan self esteem tinggi merasa yakin atas kemampuan dirinya. Narapidana tersebut memiliki ciri seperti aktif, ekspresif, mandiri, kreatif, dan percaya diri pada kemampuannya. Mereka cenderung menerima dan memberikan penghargaan positif terhadap dirinya sendiri. Pernyataan tersebut sesuai dengan pendapat Coopersmith (1967) yaitu individu yang memiliki self esteem tinggi akan puas dengan karakter dan kemampuan dirinya yang ditandai dengan adanya evaluasi diri yang positif sehingga memiliki gambaran diri yang positif, mampu menerima masukan dari lingkungannya, dapat melakukan evaluasi secara positif serta memiliki harga diri (self worth) yang positif dan mampu mengoptimalkan dan mengendalikan harga diri yang dimilikinya. 
Terbentuknya self esteem yang tinggi pada narapidana narkoba yang direhabilitasi di Lapas Narkotika tidak terlepas dari berbagai pihak yang ada didalamnya. Adanya program rehabilitasi, peran petugas Lapas serta yang terutama adalah peran keluarga dalam proses pembentukannya. Menurut Sarason (1987) bahwa pengaruh dukungan sosial yang tinggi terhadap individu akan memiliki pengalaman hidup yang lebih baik, harga diri yang lebih tinggi, serta memiliki pandangan yang lebih positif terhadap kehidupan. Artinya bahwa tingginya self esteem narapidana narkoba yang direhabilitasi disebabkan mereka telah memiliki dukungan keluarga yang tinggi. Seperti memiliki besarnya pengaruh yang positif dari keluarga sehingga terbentuk self esteem yang tinggi, serta cenderung bersikap terbuka dengan orang-orang di sekitar.

Lapas Narkotika Yogyakarta memiliki program rehabilitasi yaitu program therapeutic community yaitu program pemulihan yang mengubah perilaku adiksi penyalahguna narkoba menuju "healthy life style". Therapeutic community adalah sebuah terapi yang meliputi perhatian, perlindungan serta dukungan perkembangan secara fisik, mental, emosional, dan spiritual yang seimbang. Metode therapeutic community merupakan suatu metode rehabilitasi sosial yang ditujukan kepada korban penyalahguna narkoba, yang merupakan sebuah "keluarga" terdiri atas orang-orang yang mempunyai masalah yang sama dan memiliki tujuan yang sama yaitu menolong diri sendiri dan sesama yang oleh seseorang dari mereka, sehingga terjadi perubahan tingkah laku dari negatif ke arah tingkah laku yang positif. Metode rehabilitasi therapeutic community menekankan pada pemberian dukungan sosial. Bentuk kegiatannya berupa terapi kelompok dengan bermacam kegiatan misalnya morning meeting, morning briefing, encounter group, static group, page group, mix confrontation, sport \& recreation, function, religious session, pembentukan status holder dan seminar. Program rehabilitasi narkoba merupakan upaya terpadu yang meliputi program medis dan non-medis atau sosial dengan tujuan membantu penyalahguna narkoba melepaskan diri dari ketergantungan narkoba, meningkatkan kemampuan penyesuaian diri, membangun kepercayaan diri, dan meningkatkan kemampuan fungsional mereka sesuai dengan potensi yang dimiliki.

Hasil dalam penelitian ini menunjukkan bahwa dukungan sosial keluarga dan self esteem narapidana narkoba yang direhabilitasi tinggi, maka 
dapat dikatakan bahwa program rehabilitasi ini cukup berhasil memberikan dampak positif bagi setiap narapidana dalam memaknainya. Hal tersebut sesuai dengan hasil penelitian yang dilakukan oleh Nasution (2017) mengenai hubungan dukungan dukungan sosial dengan self esteem pada pemakai narkoba yang mengikuti rehabilitasi metode therapeutic community menunjukkan bahwa sebagian besar pemakai narkoba yang mengikuti rehabilitasi metode therapeutic community memiliki dukungan sosial yang tinggi dan self esteem yang tinggi. Selain itu hasil penelitan juga menemukan bahwa dukungan emosional atau penghargaan memiliki hubungan paling kuat dengan self esteem dibandingkan dengan bentuk dukungan lainnya.

Dari hasil kategorisasi pada skala dukungan sosial keluarga menunjukkan bahwa subjek yang termasuk dalam kategori sangat tinggi berjumlah 11 orang $(34,38 \%)$ dan kategori tinggi berjumlah 21 orang (65,62\%). Disimpulkan bahwa sebagian besar partisipan memiliki dukungan sosial keluarga yang tinggi. Kemudian kategorisasi pada skala self esteem menunjukkan bahwa subjek yang termasuk dalam kategori sangat tinggi berjumlah 5 orang $(15,62 \%)$, tinggi 25 orang $(78,12 \%)$, rendah 1 orang $(3,13 \%)$ dan sangat rendah 1 orang $(3,13 \%)$.
Disimpulkan bahwa sebagian besar partisipan memiliki self esteem yang tinggi.

\section{PENUTUP}

\section{Simpulan}

Terdapat hubungan positif yang signifikan, dengan $r=0,547$ dengan sig. $=$ $0,001 \quad(\mathrm{P}<0,05)$ antara dukungan sosial keluarga dengan self esteem. Makin tinggi dukungan sosial keluarga maka makin tinggi self esteem dan sebaliknya makin rendah dukungan sosial keluarga maka makin rendah self esteem yang dimiliki oleh narapidana narkoba yang sedang direhabilitasi di Lapas Narkotika Yogyakarta.

Sebagian besar $(65,62 \%)$ narapidana narkoba yang direhabilitasi memiliki dukungan sosial keluarga pada kategori tinggi dan sebagian besar $(78,12 \%)$ narapidana narkoba yang direhabilitasi memiliki self esteem pada kategori tinggi.

Besarnya presentase sumbangan dukungan sosial keluarga terhadap self esteem adalah 29,92\%, sedangkan sisanya $70,08 \%$ dipengaruhi oleh faktor lain.

\section{Saran}

Untuk Lapas Narkotika Yogyakarta. Pihak Lapas dalam memberikan pembinaan hendaknya memperhatikan kondisi psikologis narapidana narkoba yang direhabilitasi guna meningkatkan 
self esteem dan tetap memberikan kesempatan kepada keluarga dalam hal kunjungan terhadap narapidana narkoba yang direhabilitasi.

Untuk narapidana narkoba yang direhabilitasi. Narapidana narkoba yang direhabilitasi perlu mempertahankan bahkan meningkatkan self esteem dan selalu terbuka kepada keluarga untuk mendapatkan dukungan yang positif.

Untuk keluarga narapidana. Keluarga diharapkan terus memberikan dukungan berupa kepedulian, perhatian, bimbingan dan kepercayaan sehingga narapidana yang direhabilitasi merasa nyaman, aman, dan merasa dicintai oleh keluarga guna meningkatkan self esteem pada narapidana yang direhabilitasi.

Untuk peneliti lain. Peneliti selanjutnya disarankan untuk meneliti faktor-faktor lain seperti pengaruh kelompok teman sebaya, pengalaman dan kemampuan bertahan dari narapidana narkoba dalam proses pembentukan self esteem. Bisa juga menggunakan metode kualitatif untuk lebih mendalami dinamika psikologis pada narapidana narkoba yang sedang direhabilitasi.

\section{DAFTAR PUSTAKA}

Alavi, H. R. 2011. The Roll Of Self Esteem In Tendency Towards Drugs, Theft And Prostitution. Addict \& Health, 3 (3-4), 119-124.
Alboukordi, dkk. 2010) The Relationship Between Self-Esteem And Social Support With Depression In Male Prisoners. Journal of Mazandaran University of Medical Sciences, 77 (67), 6268.

Azwar, S. 012. Penyusunan Skala Psikologi. Yogyakarta: Pustaka Pelajar.

Coopersmith, S. 1967. The Antecendents Of Self Esteem. San Fransisco: W. H. Freeman \& Company.

Cutrona, C. E. \& Russell, D. W. 1987. The Provisions Of Social Relationships And Adaptation To Stress. Journal of Advances in Personal Relationships, 1, 37-67.

Data BNN RI. 2017. 12 Februari 2019. Survei Nasional Penyalahgunaan Narkoba Di 34 Provinsi Tahun 2017. Diambil dari https://ppid.bnn.go.id/wpcontent/uploads/sites/2/2019/01/hasi 1_lit_bnn_2017.pdf

De Leon, G. 2000. The Therapeutic Community: Theory, Model, And Method. New York: Springer.

Dixey, R., \& Woodal, J. 2012. The Significance Of The Visit In An English Category-B Prison, Prosoners' Families And Prison Staff. Community, work \& family, 15 (1), 29-47.

Herdiyanto, A. P. 2014. Hubungan Antara Dukungan Sosial Dan Self Esteem Pada Remaja Penyalahguna Zat Yang Sedang Dalam Masa Rehabilitasi. Jurnal Psikologi Klinis dan Kesehatan Mental, 2 (1), 1-6.

Husnina, H. N. \& Nugraha, S. 2016. Hubungan Social Support Dengan Self Esteem Pada Andikpas Di 
Lembaga Pembinaan Khusus Anak (LPKA) Kelas Ii Bandung. Porsiding Psikologi, 2 (1), 277-282.

Jiang, S., Ohio, L. T., \& Winfree J. 2006. Social Support, Gender, And Inmate Adjustment To Prison Life. The Prison Journal, 8 (1), 32-55.

Kemenkumham DIY. 2016. Berita Upt Kemenkumham DIY. 12 Februari 2019. Diambil dari https://jogja.kemenkumham.go.id/be rita-kanwil/berita-upt/2839gelombang-pertama-2016-lapasnarkotika-yogyakarta-rehabilitasi52-pecandu.

Kristianingsih, S. A. 2009. Pemaknaan Pemenjaraan Pada Narapidana Narkoba Di Rumah Tahanan Salatiga. Humanitas, 6 (1), 1-15.

Mann, M., Hosman, C. M., Schaalma H. P., De Vries N. K. 2004. SelfEsteem In A Broadspectrum Approach For Mental Health Promotion. Health Education Research, 19 (4), 357-372.

Myers, D. G. 2012. Psikologi Sosial. Jakarta: Salemba Humanika.
Nasution, N. H. 2007. Hubungan Dukungan Sosial Dengan Self Esteem Pada Pemakai Narkoba Yang Mengikuti Rehabilitasi Metode Therapeutic Community (Skripsi). Diambil dari http://repositori.usu.ac.id/handle/123 $456789 / 7489$

Nelfice, E. V., \& Dewi, Y. I. 2014. Hubungan Dukungan Keluarga Dengan Harga Diri Remaja Di Lembaga Pemasyarakatan. Journal of Medicine Psikologi, 1, 1-10.

Nurhidayati, N. 2014. Hubungan Antara Dukungan Sosial Keluarga Dengan Self Esteem Pada Penyalahguna Narkoba Yang Direhabilitasi. Jurnal Psikologi Klinis dan Kesehatan Mental, 3 (3), 52-59.

Papalia, dkk. 2008. Psikologi Perkembangan. Jakarta: Kencana.

Sarason. B. R. 1987. Interelation of Social Support Measures: Theoritical And Practical Implications. Journal of Personality and Social Psychology, 52, 813-832. 